\title{
Tissue preparation for immunocytochemistry
}

\author{
J H Williams, B L Mepham, D H Wright
}

\begin{abstract}
Aims-To investigate the effect of tissue preparation on immunostaining and to establish whether there is a standard tissue preparation schedule that allows optimal demonstration of all antigens. Methods-Blocks of tonsil were subjected to variations to a standard fixation, processing, and section preparation schedule. The sections were stained with five antibodies-L26 (CD20), UCHL1 (CD45RO), CD3, vimentin, and antikappa light chain-using the streptavidinbiotin immunostaining technique. When further investigation was necessary, other tissues and antibodies were used and where weak immunostaining was obtained the use of microwave pretreatment to improve staining was tested.
\end{abstract}

Results-Several factors involved in fixation were found to affect immunoreactivity. These included the duration, $\mathrm{pH}$, and type of fixative used. In tissue processing only temperature and the duration of the dehydration and wax infiltration steps affected immunoreactivity. Of all the factors investigated, the temperature and duration of the section drying had the greatest effect. In contrast, long term storage of cut sections before immunostaining had no effect on the reactivity of the antibodies tested. Antibodies were found to be affected by alterations to tissue preparation by varying degrees, UCHL1 and vimentin being the most susceptible to changes in fixation and L26 to changes in processing. Where weak staining occurred, microwave pretreatment was generally found to eliminate the problem.

Conclusions-There is no standard tissue preparation schedule for the optimal demonstration of all antigens. Factors involved in all aspects of tissue preparation can affect immunoreactivity, so it is important that precise details of the preparation schedule are given when reporting immunocytochemical studies, rather than using the general term "routinely fixed and processed".

(f Clin Pathol 1997;50:422-428)

Keywords: immunocytochemistry; fixation; tissue preparation

The most common cause of poor immunostaining in paraffin wax embedded tissue is not the technique itself but the alteration of the antigenic sites by the initial process of tissue preparation $^{1}$ which incorporates fixation, processing, and the preparation of the tissue sections. The establishment of a tissue preparation schedule for optimal immunostaining of all antigens has been a problem since immunocytochemical staining of paraffin embedded tissue was first developed. ${ }^{2}$ Since that time several studies have been undertaken to investigate this problem, although these have mainly been concerned with fixation rather than with tissue processing or section preparation.

Tissue fixation has a significant influence on immunostaining as most antigens are altered during the process. Fixation involves a number of variables including the type, concentration, $\mathrm{pH}$, and osmolarity of the fixative, and the duration and temperature of the fixation process; all of which can affect immunocytochemistry. Other factors reported to affect fixation and therefore possibly immunoreactivity are the volume of fixative, ${ }^{3}$ delayed fixation, ${ }^{4-8}$ or secondary fixation by alcohol-either during fixation by methanol which is added as a preservative to commercially prepared formalin ${ }^{9}$ or in alcohol during processing if fixation is incomplete. ${ }^{10-13}$

In contrast to the number of studies on the effect of fixation on immunoreactivity, investigations into the effect of tissue processing have been limited; weak immunostaining because of poor tissue preparation being blamed on inadequate fixation rather than on other aspects of tissue preparation. It was reported in the late 1980 s, shortly after the development of the enclosed tissue processor, that the use of this system could cause problems with both tissue and antigen preservation. This was either through carryover of reagents from one step to the next, in particular xylene from the wax cleansing cycle at the end of the programme into the first step of the cycle, ${ }^{14-16}$ or through the use of inferior quality xylene during processing. ${ }^{15}$ The type of reagent and the timing and temperature used for each step of processing (dehydration, clearing, and wax infiltration) have also been reported to affect immunoreactivity. ${ }^{17-22}$ Other factors which can affect processing and therefore possibly immunoreactivity are the use of xylene as a substitute for water to make up graded alcohols, ${ }^{23}$ and the application of vacuum during processing. ${ }^{24}$

No studies have exclusively investigated the effect on immunoreactivity of section preparation, which includes wax embedding, section cutting and drying, and subsequent section storage. It has been suggested that the use of lower drying temperatures or shorter times ${ }^{25-29}$ and the avoidance of long term storage of cut sections can help preserve immunoreactivity. ${ }^{30-32}$ 
The introduction of antigen retrieval by heating tissue sections in a microwave ${ }^{33}$ or pressure cooker ${ }^{34}{ }^{35}$ before immunostaining has been a major breakthrough in improving weak immunoreactivity, particularly in suboptimally prepared tissue. ${ }^{12} 34$

The aim of this study was to investigate all aspects of tissue fixation, processing, and section preparation and their effect on subsequent immunostaining, to establish a standard tissue preparation schedule which would allow optimal staining of all antigens. This was carried out using primary antibodies which from experience were known to be fixation or processing dependent to varying degrees.

\section{Methods}

TISSUE PREPARATION

Tonsils were obtained fresh from the operating theatre, cut into $2 \mathrm{~mm}$ slices, and subjected to a number of variations to a standard fixation, processing, and section preparation protocol. Each block was subjected to variation of only one of the three components of tissue preparation, the other two remaining standard. The standard tissue preparation protocol comprised fixation for 24 hours in $10 \%$ neutral buffered formalin (NBF) at room temperature in $50 \mathrm{ml}$ of fixative, followed by processing on a 16 hour overnight schedule at ambient temperature on a Shandon Hypercenter 2 (Life Sciences International, Basingstoke, UK) (table 1). Paraffin sections were cut at $4 \mathrm{~mm}$, mounted on 3-aminopropyltriethoxysilane coated slides, and dried at $37^{\circ} \mathrm{C}$ overnight.

\section{Variations to fixation protocol}

(1) Different types of fixative:
(a) $10 \% \mathrm{NBF}^{36}$;
(b) $10 \%$ formalin in tap water ${ }^{36}$;
(c) $10 \%$ formal saline ${ }^{36}$;
(d) $10 \%$ neutral buffered formalin with saline (NBFS);
(e) $10 \%$ formal acetic ${ }^{37}$;
(f) $10 \%$ zinc formalin 38 ;
(g) Carson's fixative ${ }^{39}$;
(h) Bouin's fixative ${ }^{36}$;
(i) $\mathrm{B} 5 .^{40}$

(2) Period of fixation: $<5,5,12,24,36$, and 48 hours.

(3) Temperature of fixation: $18^{\circ} \mathrm{C}, 27^{\circ} \mathrm{C}$, and $37^{\circ} \mathrm{C}$.

(4) $\mathrm{pH}$ of $10 \%$ formalin: $\mathrm{pH} 3.0,5.0,7.0,9.0$, and 11.0 .

(5) Delay before fixation: $0,1,2,4$, and 8 hours.

(6) Different volumes of formalin: ratio of tissue:formalin of $1: 1$ to $1: 20$.

(7) Addition of methanol to formalin: 0, 0.25, $0.5,1,1.5,2$, and $5 \%$.

Variations to processing protocol

(1) Comparison between the carousel type and the enclosed vacuum processor.

(2) Comparison of different clearing agents with xylene:

(a) chloroform;

(b) Clearene (Surgipath, St Neots, UK);

(c) xylene substitute (Shandon).

(3) Comparison of different paraffin waxes: (a) non-polymer (Ames Tissue Tek II, Bayer, Newbury, UK);

(b) polymer (Ames Tissue Tek III, Bayer);

(c) polymer + DMSO ("Paramat extra", Merck, Poole, UK);

(d) microcrystalline (Fibrowax, Merck).

(4) Reduced and extended processing times for dehydration, clearing and wax infiltration.

(5) Temperature of processing: ambient and $45^{\circ} \mathrm{C}$.

(6) Use of vacuum during all processing steps.

(7) Number of blocks and position of tissue in the carrier during processing.

(8) Xylene contamination of formalin.

(9) Comparison between repeated use of high and lower quality xylene for clearing.

Variations to section preparation protocol

(1) Dried at either $37^{\circ} \mathrm{C}$ overnight in a section drying oven, $60^{\circ} \mathrm{C}$ for 1,4 , or 8 hours and overnight in an incubator, or face down on a section drying hotplate at approximately $70^{\circ} \mathrm{C}$ for $0.5,2$, and 8 hours.

(2) Dried at $37^{\circ} \mathrm{C}$ overnight and stored for 1 day, 1 week, 1, 3, and 6 months at room temperature and $4^{\circ} \mathrm{C}$ before immunostain-

Table 1 Standard processing schedule

\begin{tabular}{|c|c|c|c|c|}
\hline Station & Reagent & Temperature & Vacuum & Time (h) \\
\hline 2 & $70 \%$ alcohol & A & $\mathrm{Y}$ & 1 \\
\hline 3 & $90 \%$ alcohol & A & $\mathrm{Y}$ & 1 \\
\hline 4 & $100 \%$ alcohol & A & $\mathrm{Y}$ & 0.5 \\
\hline 5 & $100 \%$ alcohol & A & $\mathrm{Y}$ & 1 \\
\hline 6 & $100 \%$ alcohol & A & $\mathrm{Y}$ & 2 \\
\hline 7 & $100 \%$ alcohol & A & $\mathrm{Y}$ & 2 \\
\hline \multirow[t]{2}{*}{8} & Xylene:alcohol & & & \\
\hline & $(50: 50)$ & A & $\mathrm{Y}$ & 1 \\
\hline 9 & Xylene & A & $\mathrm{Y}$ & 1.5 \\
\hline 10 & Xylene & A & $\mathrm{Y}$ & 1.5 \\
\hline 11 & $\begin{array}{l}\text { Lambwax } \\
\text { (RA Lamb, } \\
\text { London, UK) }\end{array}$ & $60^{\circ} \mathrm{C}$ & $\mathrm{Y}$ & 1.5 \\
\hline \multirow[t]{2}{*}{12} & $\begin{array}{l}\text { Lambwax } \\
\text { Total processing }\end{array}$ & $60^{\circ} \mathrm{C}$ & $\mathrm{Y}$ & 3 \\
\hline & time & & & 16 \\
\hline
\end{tabular}

A, ambient temperature.

Table 2 Main panel of primary antibodies used

\begin{tabular}{llllll}
\hline Antibody & CD No & Supplier & Cat No & Dilution & $\begin{array}{l}\text { Pre- } \\
\text { treatment }\end{array}$ \\
\hline L26 & CD20 & Dako & M755 & $1 / 1000$ & NT \\
UCHL1 & CD45RO & Dako & M742 & $1 / 100$ & NT \\
CD3 & CD3 & Dako & A452 & $1 / 200$ & $+\mathrm{T}$ \\
Vimentin & - & Dako & M7020 & $1 / 1000$ & $+\mathrm{T}$ \\
$\begin{array}{l}\quad \text { (3B4) } \\
\text { Kappa }\end{array}$ & - & Dako & A191 & $1 / 500$ & $+\mathrm{T}$ \\
\hline
\end{tabular}

NT, no pretreatment; $+\mathrm{T}$, trypsin pretreatment.

Table 3 Additional antibodies used for section preparation experiments

\begin{tabular}{lllll}
\hline Antibody & Supplier & Cat No & Dilution & Pretreatment \\
\hline MIB1 & Binding & & & \\
& Site & 0505 & $1 / 1000$ & $+\mathrm{MW}$ \\
PC10 & Gift & - & $1 / 800$ & $+\mathrm{T}$ \\
1D5 & Dako & M7047 & $1 / 500$ & $+\mathrm{MW}$ \\
BCL-2 & Dako & M887 & $1 / 150$ & $+\mathrm{MW}$ \\
aSMA & Dako & M851 & $1 / 2000$ & $+\mathrm{MW}$ \\
CEA & Dako & M7072 & $1 / 400$ & $+\mathrm{T}$ \\
Vimentin & & & & \\
$\quad$ V9) & Dako & M725 & $1 / 2000$ & $+\mathrm{MW}$ \\
Desmin & Dako & M760 & $1 / 500$ & NT \\
\hline
\end{tabular}

NT, no pretreatment; $+\mathrm{T}$, trypsin pretreatment; +MW, microwave pretreatment.

*Birmingham, UK; † Kindly donated by David Lane, University of Dundee. 
Table 4 Summary of immunostaining results after increasing fixation time in formalin

\begin{tabular}{lllllll}
\hline Antibody & $<5 h^{\star}$ & $5 h$ & $12 h$ & $24 h$ & $36 h$ & $48 h$ \\
\hline L26 & +++ & +++ & +++ & +++ & +++ & +++ \\
UCHL1 & +++ & +++ & +++ & ++ & ++ & + \\
CD3 & ++ & ++ & +++ & +++ & +++ & +++ \\
Vimentin & + & +++ & +++ & +++ & ++ & ++ \\
Kappa & - & ++ & +++ & +++ & +++ & +++
\end{tabular}

«No trypsin digestion was used on sections fixed for $<5$ hours as even very short pretreatment times of less than 30 seconds severely disrupted the tissue.

ing. The section cutting was staggered from six months to one day so that all the sections could be stained at the same time.

IMMUNOSTAINING

Sections from each experiment were stained with a panel of five primary antibodies (table 2 ). For the section preparation experiments additional tissues and antibodies were included (table 3). The primary antibodies were demonstrated using the StreptABC peroxidase (HRP) method as follows: sections were dewaxed and taken through to $70 \%$ alcohol before treating with $0.5 \%$ hydrogen peroxide for 10 minutes to inhibit endogenous peroxidase. Sections were then pretreated as required for each antibody (tables 2 and 3 ) and the trypsin time was adjusted for each section to take into account the type and period of fixation used. Sections were rinsed in Tris buffered saline (TBS) and incubated in primary antibody for the appropriate time, that is, polyclonal immunoglobulins, 30 minutes at room temperature; monoclonal and other polyclonal antibodies, overnight at $4^{\circ} \mathrm{C}$. After a further rinse in TBS, sections were incubated in the relevant biotinylated second stage (Dako, High Wycombe, $\mathrm{UK}$ ) for 30 minutes at room temperature, followed by incubation in StreptABC HRP complex (Dako) for the same period of time. The HRP was visualised by reacting with diaminobenzidine $/ \mathrm{H}_{2} \mathrm{O}_{2}$ (Sigma Fast, Sigma, Poole, UK) for 10 minutes. After washing, the sections were counterstained in Harris haematoxylin, blued in tap water, dehydrated through alcohol to xylene, and mounted in DPX.

\section{ASSESSMENT OF STAINING}

The stained sections were examined independently by two of the authors (BLM and JHW) without prior knowledge of the section treatment. The two sets of results were then compared and any which differed by one grade or more were re-examined by the two assessors together. If there were any further discrepancies the slides were re-assessed by the third author (DHW). The grades for recording
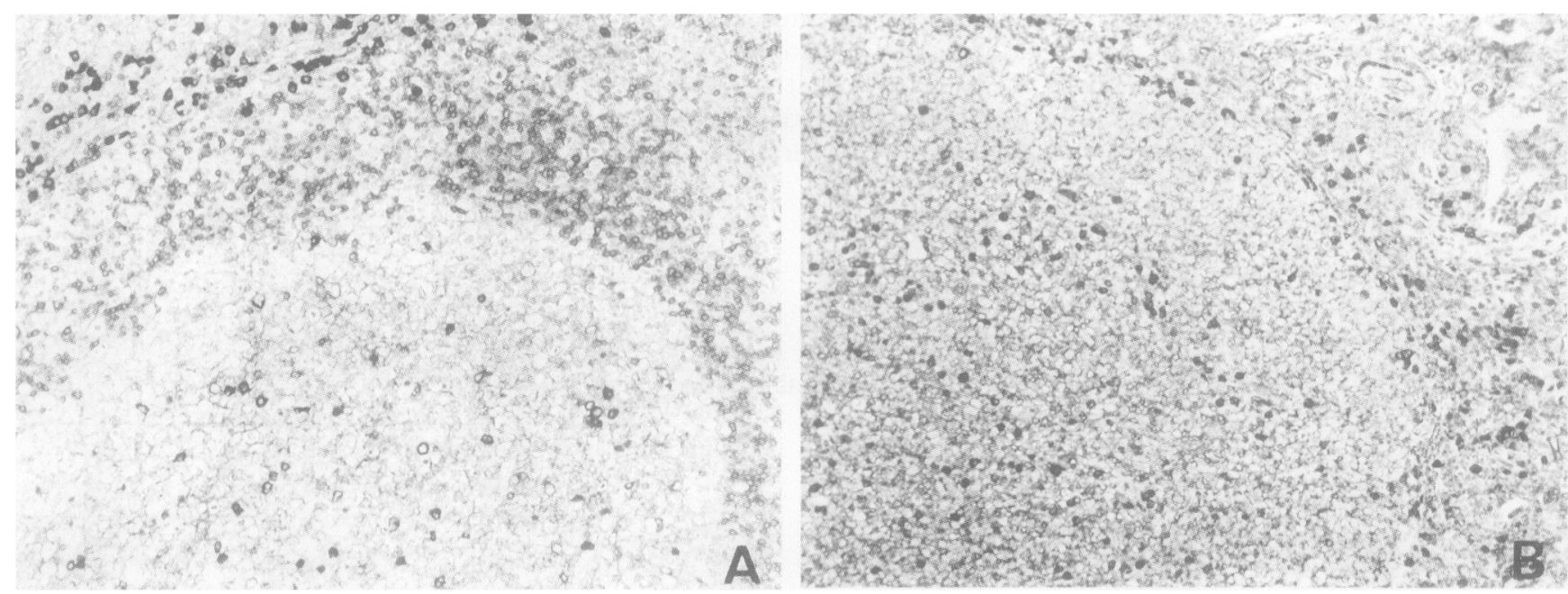

Figure 1 Sections of tonsil fixed in 10\% NBF (A) and 10\% formal acetic (B) stained for kappa light chain. Tissue fixed in 10\% NBF shows staining of follicle centre cells, mantle cells, and plasma cells. Mantle cell staining is not seen in (B).
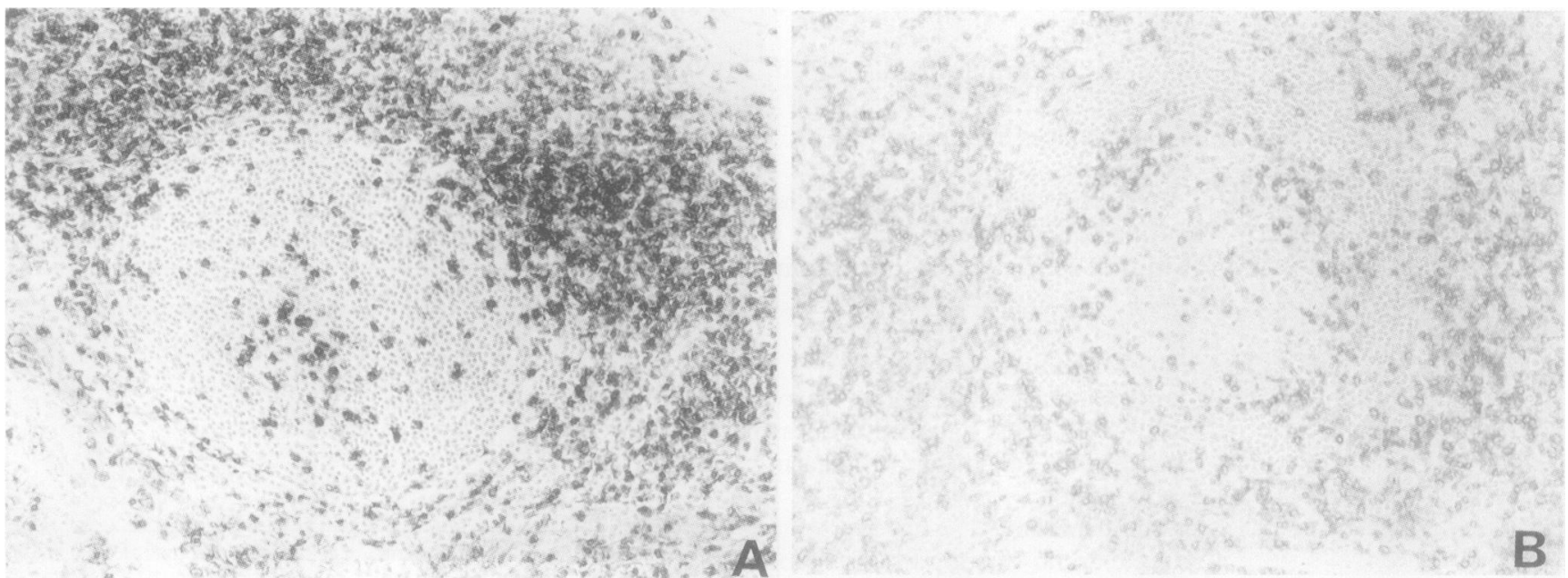

Figure 2 Sections of tonsil fixed for $<5$ hours $(A)$ and 48 hours $(B)$ in $10 \% \mathrm{NBF}$ and stained with UCHL1. Much stronger staining is seen with the shorter period of fixation. 
Table 5 Summary of immunostaining results after varying the $\mathrm{pH}$ of formalin

\begin{tabular}{llllll}
\hline Antibody & pH 3.0 & pH 5.0 & pH 7.0 & pH 9.0 & pH 11.0 \\
\hline L26 & +++ & +++ & +++ & +++ & +++ \\
UCHL1 & +++ & ++ & ++ & + & + \\
CD3 & ++ & +++ & +++ & +++ & ++ \\
Vimentin & +++ & ++ & ++ & + & + \\
Kappa & +++ & +++ & +++ & +++ & ++ \\
\hline
\end{tabular}

intensity of specific staining were as follows: $>+++$, excellent; +++ , very good; ++ , moderate; + , weak; $+/-$, very weak; - , no staining.

\section{USE OF MICROWAVE PRETREATMENT}

Where weak staining was obtained with antibodies not usually requiring heat retrieval, the staining was repeated using microwave pretreatment.

\section{Results}

FIXATION

Several of the factors involved in the process of fixation were found to affect immunoreactivity of some of the antibodies tested. These included the type, duration, and $\mathrm{pH}$ of the fixative. Of the types of fixatives tested, $10 \%$ formal saline, $10 \% \mathrm{NBF}$ (except UCHL1), and
$10 \%$ zinc formalin (except CD3) gave the most consistent results overall and showed excellent antigen preservation. Of those recommended for immunocytochemistry, $10 \%$ formal acetic (fig 1), B5, and Bouin's fixative all showed poor antigen preservation. The use of B5 fixative resulted in high levels of background staining. This was not improved by the use of microwave pretreatment. Staining after Bouin's fixation was weak, although the use of microwaving did enhance staining with L26 and UCHL1 but not with $\mathrm{CD} 3$ and vimentin. Only weak immunostaining was obtained after using both the traditionally used fixatives- $10 \%$ NBFS and $10 \%$ formalin in tap water-and the less commonly used Carson's fixative.

The period of fixation (table 4; figs 2 and 3 ) and the $\mathrm{pH}$ of formalin (table 5; fig 4) also significantly affected the immunoreactivity of some of the antigens. UCHL1 and vimentin were particularly susceptible to both longer fixation times and higher $\mathrm{pH}$. In contrast, the demonstration of both kappa and CD3 improved with increasing fixation times but was less affected by changing the $\mathrm{pH}$.

The other fixation factors tested-delay before fixation, volume of fixative, and the
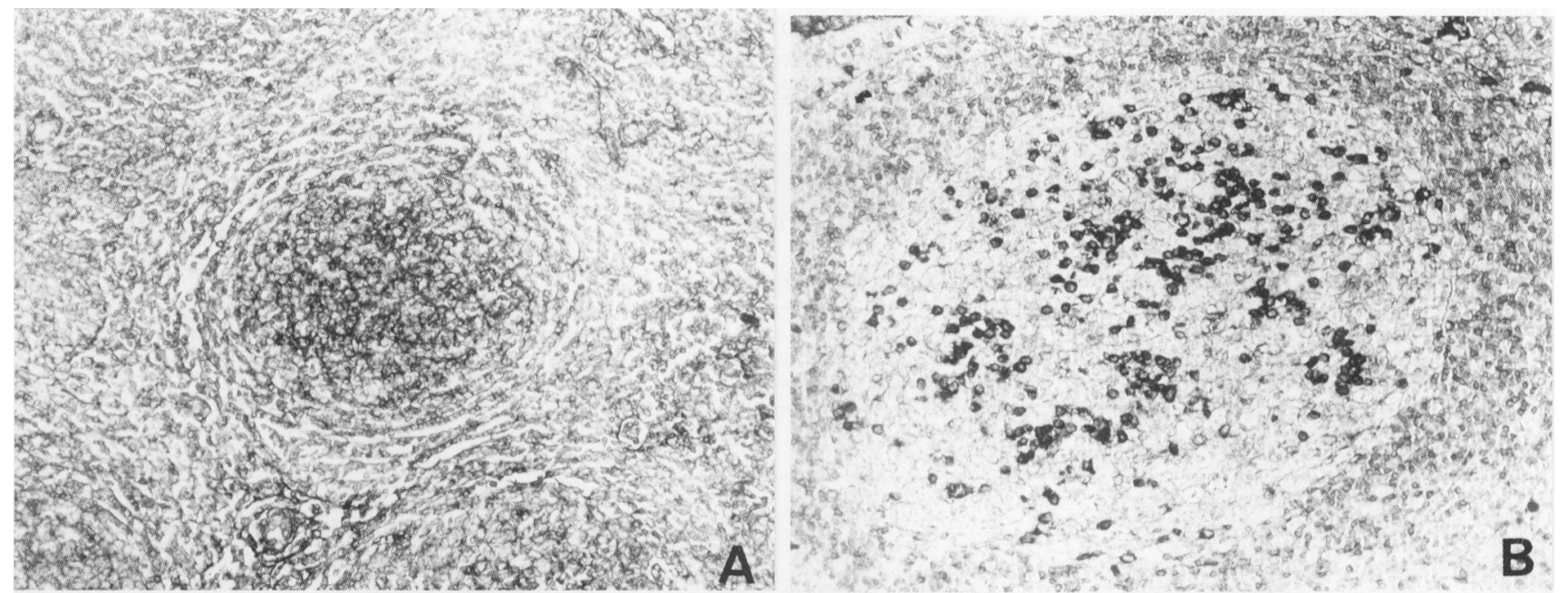

Figure 3 Sections of tonsil fixed for $<5$ hours $(A)$ and 48 hours $(B)$ in $10 \%$ NBF and stained with kappa light chain. Tissue fixed for $<5$ hours shows poor staining and appears overdigested, even though no trypsin pretreatment was used; 48 hours fixation results in clear staining of follicle centre cells, mantle cells, and plasma cells.

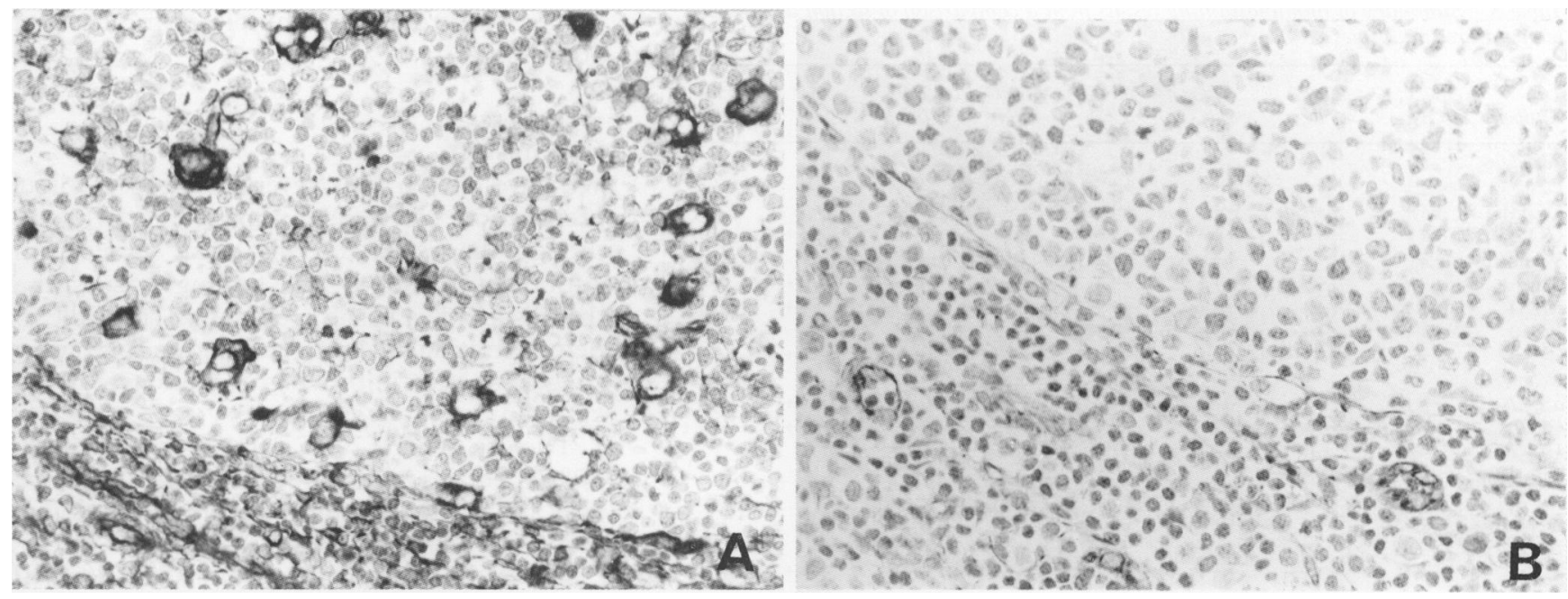

Figure 4 Sections of tonsil fixed in $10 \%$ formalin at $p H 3.0(A)$ and $p H 11.0$ (B) and stained with vimentin. The staining in (B) is clearly much weaker than in $(A)$. 


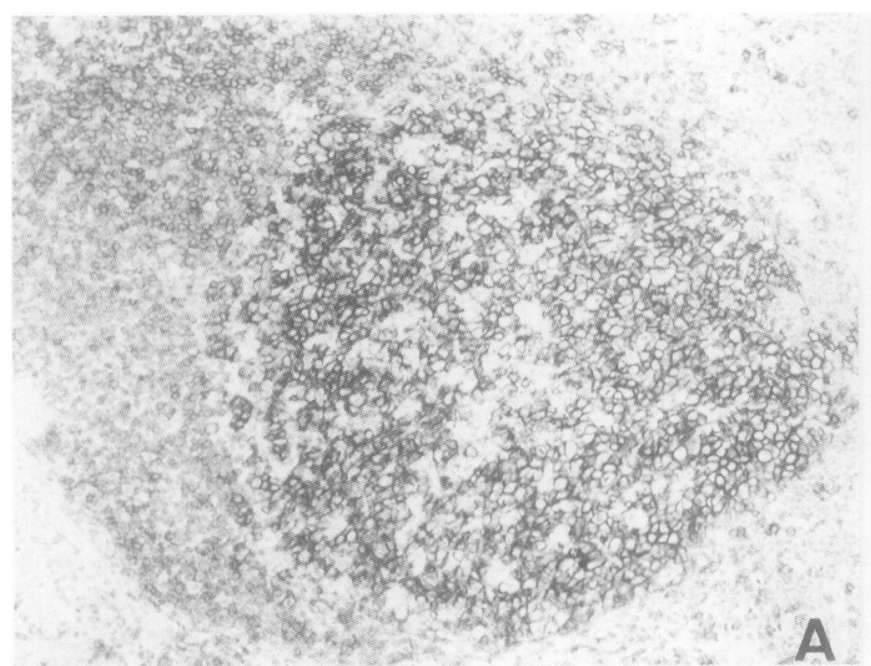

Figure 5 Sections of tonsil processed at ambient temperature $(A)$ and at $45^{\circ} \mathrm{C}(B)$ and stained with L26. The higher processing temperature gives stronger staining of $B$ cells.

Table 6 Summary of immunostaining results from comparison of processing temperatures

Antibody Ambient $45^{\circ} \mathrm{C}$

\begin{tabular}{lll}
\hline L26 & +++ & $>+++$ \\
UCHL1 & +++ & $>+++$ \\
CD3 & +++ & $>+++$ \\
Vimentin & ++ & +++ \\
Kappa & ++ & ++ \\
\hline
\end{tabular}

addition of methanol to formalin-had no effect. Increasing the temperature of fixation was generally found to produce the same results as increasing the time in fixative.

\section{PROCESSING}

Increasing the processing temperature from ambient to $45^{\circ} \mathrm{C}$ for all stages up to the wax infiltration step (table 6; fig 5) and increasing the duration of both the dehydration and wax infiltration stages (table 7) improved the immunostaining of most of the antibodies tested. None of the other factors investigatedthe type of processor, type and quality of reagent, use of vacuum, xylene contamination

Table 7 Summary of immunostaining from comparison of different processing times

\begin{tabular}{|c|c|c|c|c|c|c|}
\hline \multirow[b]{3}{*}{ Antibody } & \multicolumn{3}{|c|}{ Dehydration } & \multicolumn{3}{|c|}{ Wax infiltration } \\
\hline & \multicolumn{3}{|c|}{ Total dehydration times } & \multicolumn{3}{|c|}{ Total wax infiltration times } \\
\hline & $\begin{array}{l}\text { Reduced } \\
(2 \mathrm{~h})\end{array}$ & $\begin{array}{l}\text { Standard } \\
(7.5 h)\end{array}$ & $\begin{array}{l}\text { Extended } \\
(10 \mathrm{~h})\end{array}$ & $\begin{array}{l}\text { Reduced } \\
(2 h)\end{array}$ & $\begin{array}{l}\text { Standard } \\
(4 h)\end{array}$ & $\begin{array}{l}\text { Extended } \\
(8 h)\end{array}$ \\
\hline $\mathrm{L} 26$ & ++ & +++ & $>+++$ & + & ++ & +++ \\
\hline UCHL1 & +++ & +++ & +++ & ++ & ++ & +++ \\
\hline CD3 & +++ & +++ & +++ & ++ & ++ & ++ \\
\hline Vimentin & +++ & +++ & +++ & ++ & ++ & ++ \\
\hline Kappa & ++ & +++ & +++ & ++ & ++ & ++ \\
\hline
\end{tabular}

Table 8 Summary of immunostaining results from a comparison of section drying temperatures and times

\begin{tabular}{|c|c|c|c|c|c|c|c|c|}
\hline Antibody & $\begin{array}{l}37^{\circ} \mathrm{C} \\
O N\end{array}$ & $\begin{array}{l}60^{\circ} \mathrm{C} \\
1 \mathrm{~h}\end{array}$ & $\begin{array}{l}60^{\circ} \mathrm{C} \\
4 h\end{array}$ & $\begin{array}{l}60^{\circ} \mathrm{C} \\
8 h\end{array}$ & $\begin{array}{l}60^{\circ} \mathrm{C} \\
\mathrm{ON}\end{array}$ & $\begin{array}{l}H P \\
0.5 h\end{array}$ & $\begin{array}{l}H P \\
2 h\end{array}$ & $\begin{array}{l}H P \\
8 h\end{array}$ \\
\hline \multicolumn{9}{|l|}{ Tonsil } \\
\hline L26 & +++ & ++ & ++ & ++ & + & + & + & + \\
\hline UCHL1 & +++ & +++ & ++ & ++ & ++ & $+1-$ & $+1-$ & - \\
\hline $\mathrm{CD}^{\star}{ }^{\star}$ & +++ & +++ & +++ & +++ & +++ & +++ & +++ & +++ \\
\hline Vimentin & ++ & ++ & ++ & ++ & ++ & ++ & ++ & ++ \\
\hline Kappa & +++ & +++ & +++ & ++ & ++ & +++ & +++ & +++ \\
\hline MIB1 & +++ & +++ & +++ & +++ & +++ & +++ & +++ & +++ \\
\hline PC10 & +++ & +++ & +++ & +++ & ++ & + & + & - \\
\hline $\begin{array}{l}\text { BCL-2 } \\
\text { Colon }\end{array}$ & +++ & +++ & +++ & +++ & +++ & +++ & +++ & +++ \\
\hline$\alpha \mathrm{SMA}$ & +++ & +++ & +++ & +++ & +++ & +++ & +++ & ++ \\
\hline CEA & +++ & +++ & +++ & +++ & +++ & +++ & +++ & +++ \\
\hline \multicolumn{9}{|l|}{ Uterus } \\
\hline \multicolumn{9}{|l|}{ Vimentin } \\
\hline (V9) & +++ & +++ & +++ & +++ & +++ & +++ & ++ & + \\
\hline Desmin & +++ & +++ & ++ & ++ & $+1-$ & + & + & - \\
\hline \multicolumn{9}{|l|}{ Breast } \\
\hline 1D5 & +++ & +++ & +++ & +++ & +++ & +++ & +++ & + \\
\hline
\end{tabular}

$\mathrm{ON}$, overnight; $\mathrm{HP}$, hotplate at $70^{\circ} \mathrm{C}$.

^Background staining increased with increasing temperature/time. of formalin, length of clearing stage, and the number and position of the tissue in the carrier-had any effect.

SECTION PREPARATION

The temperature and duration of section drying was found to affect immunoreactivity of several of the antibodies tested (table 8; figs 6 and 7 ). In contrast with section drying it was found that, with the exception of desmin, the immunoreactivity of all antigens was unaffected in sections stored at room temperature or at $+4^{\circ} \mathrm{C}$ for up to six months after cutting.

USE OF MICROWAVE PRETREATMENT

The use of microwave pretreatment was found to reduce or eliminate most of the weak staining occurring in this study: it improved immunostaining of L26 and UCHL1 in Bouin's fixed tissue; it improved CD3 staining in tissue fixed for less than five hours; and it significantly improved immunostaining with UCHL1 and L26 in sections dried at higher temperatures and for longer periods.

The only exceptions were: immunostaining of all antibodies in B5 fixed tissue; CD3 and vimentin staining in Bouin's fixed tissue; vimentin staining in tissue fixed for less than five hours; and staining of most antibodies if sections were dried on a hotplate for more than 30 minutes.

\section{Discussion}

We have shown that several factors in tissue preparation can affect immunoreactivity, although the extent of this effect varies from antibody to antibody. The findings suggest that there is no ideal tissue preparation schedule for demonstrating all antigens, although various suggestions for improving immunocytochemical staining can be made.

The use of $10 \% \mathrm{NBF}, 10 \%$ zinc formalin, or $10 \%$ formal saline is recommended, particularly for demonstrating kappa light chains on mantle and follicle centre cells.

A fixation time of 12 hours in $10 \% \mathrm{NBF}$ showed optimum staining of all antigens, but as such a defined time does not allow for variation 
of tissue type and composition and for the day to day working of the laboratory, a fixation time of between 12 and 24 hours is recommended.

The $\mathrm{pH}$ of formalin affected different antigens to varying degrees. A highly acidic formalin of $\mathrm{pH} 3.0$ produced the best immunostaining but in our experience at the expense of morphology. The use of formalin at $\mathrm{pH} 5.0$ is therefore recommended giving good morphology and immunoreactivity.

Generally the other factors involved in fixation had little effect on the intensity of immunostaining provided that the recommended type, time, and $\mathrm{pH}$ of fixative were used.

Of the nine tissue processing factors investigated, only two had any significant effect on immunoreactivity. Increasing the temperature of processing from ambient to $45^{\circ} \mathrm{C}$, and longer processing times for dehydration and wax infiltration were both found to improve immunostaining. It is therefore recommended that wherever possible longer processing times at higher temperatures should be used, and the use of a short daytime schedule should be avoided for immunocytochemical studies. We found no effect of varying the other tissue processing factors, including the type of processor, type and quality of reagents, time in clearing agent, and use of vacuum, most of which have been suggested as possible causes of poor processing. ${ }^{14-17} 19$

The conditions of section preparation have mainly been ignored, but we have shown that one of the fundamental steps of section preparation-section drying - can have a significant effect on immunoreactivity. It is recommended that sections, regardless of the antigen to be demonstrated, should be dried overnight at $37^{\circ} \mathrm{C}$. If they are required more rapidly, then drying at $60^{\circ} \mathrm{C}$ for up to four hours is acceptable, particularly if followed by microwave pretreatment. The use of a hotplate $\left(70^{\circ} \mathrm{C}\right)$ for section drying should be avoided as the staining with several of the antibodies tested was reduced and could not be improved by microwave pretreatment. In contrast to the findings of others, ${ }^{30-32}$ this study has shown that with the exception of desmin (clone D33) all antibodies stained strongly in sections cut and stored for up to six months at either room temperature or $+4^{\circ} \mathrm{C}$.

It has been stated that heat pretreatment enhances immunoreactivity and evens out irregular staining due to inadequate tissue fixation or processing, ${ }^{12} 34$ and this is supported by the findings of this study. It should be noted that microwave pretreatment does not always
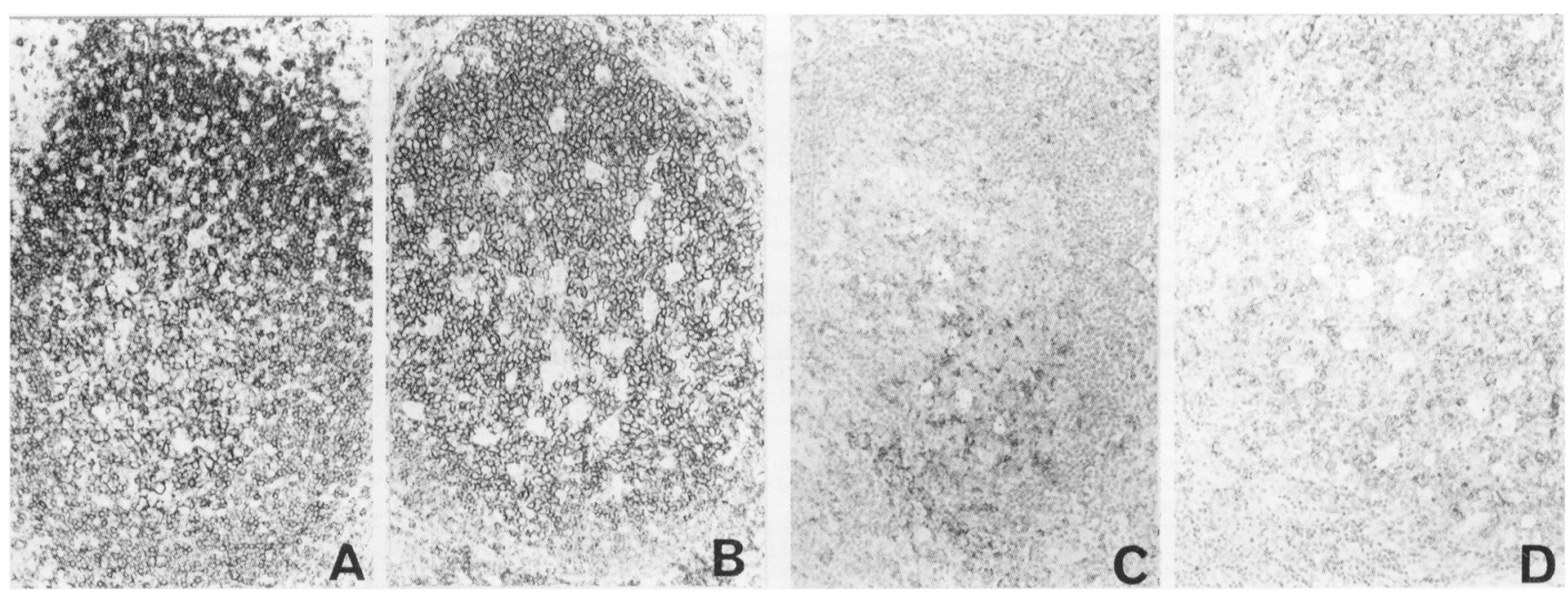

Figure 6 Sections of tonsil stained with L26 following section drying at $37^{\circ} \mathrm{C}$ overnight $(A), 60^{\circ} \mathrm{C}$ for 4 hours $(B), 60^{\circ} \mathrm{C}$ overnight $(C)$, and on a hotplate for 30 minutes (D). The results show the adverse effect of drying sections at high temperatures on a hotplate or for long periods at $60^{\circ} \mathrm{C}$.
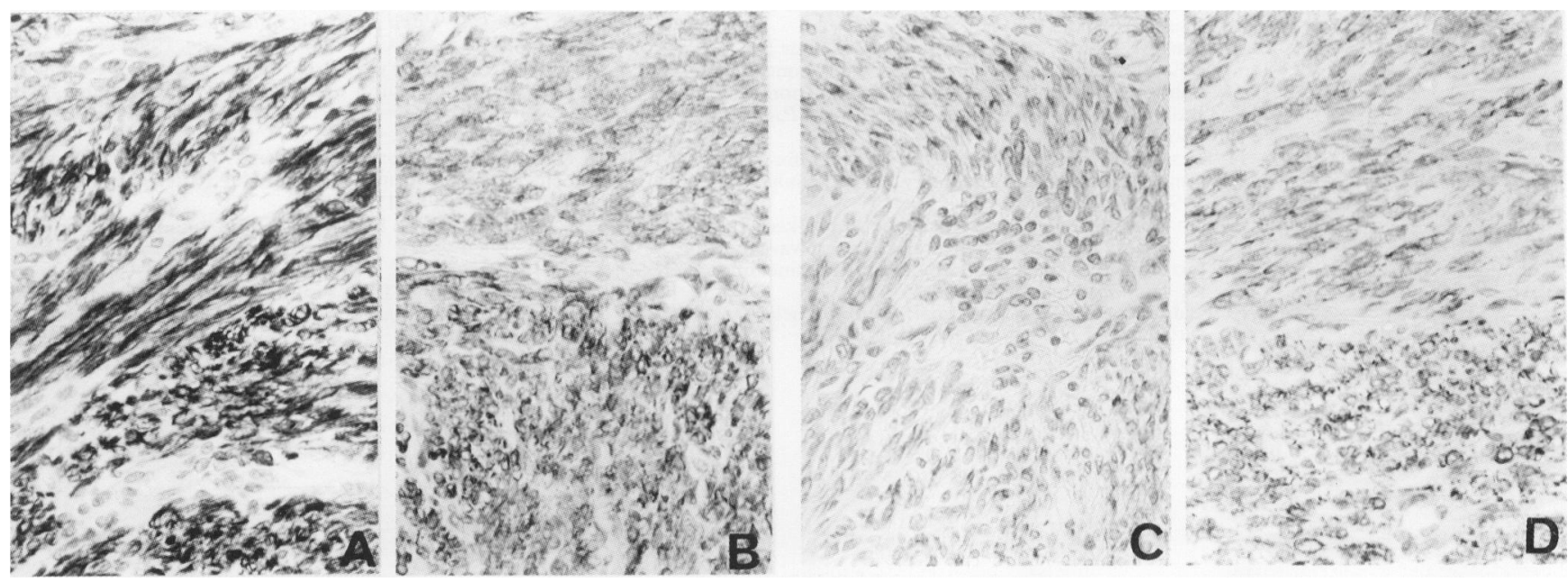

Figure 7 Sections of myometrium stained for desmin following section drying at $37^{\circ} \mathrm{C}$ overnight $(A), 60^{\circ} \mathrm{C}$ for 4 hours $(B), 60^{\circ} \mathrm{C}$ overnight $(C)$, and on a hotplate for 30 minutes (D). The adverse effect of high section drying temperatures is clearly shown. 
overcome the problem-for example, after the use of high section drying temperatures. It is therefore suggested that "prevention is better than a cure", in that it is preferable to minimise the chance of weak staining by using an optimised fixation and processing schedule rather than producing sections which have to be heat pretreated for immunostaining to be achieved.

Several of our findings are contrary to those reported by others and this can be explained by the variable response of different antigens to the effects of tissue preparation. We therefore conclude that there is no standard universal tissue preparation schedule for the optimal demonstration of all antigens, although the immunostaining of the majority of antigens can be optimised by following the recommendations given in this report.

The results of this study have shown the importance of resisting the pressure for shorter preparation times for tissue requiring immunocytochemistry, as increased processing and section drying times enhances immunoreactivity. The results have also emphasised the importance of including precise details of tissue preparation when reporting immunocytochemical findings rather than using the commonly used term "routinely fixed and processed."

We thank Dako A/S, Denmark, for kindly sponsoring the study and Dako UK for providing most of the antibodies.

1 Battifora $H$. Assessment of antigen damage in attifora H. Assessment of antigen damage in immunohistochemistry-the vim

2 Taylor CR, Burns J. The demonstration of plasma cells and other immunoglobulin-containing cells in formalin-fixed paraffin-embedded tissues using peroxidase-labelled antibody. F Clin Pathol 1974;27:14-20.

3 Drury RAB, Wallington EA. Preparation and fixation of tissues. In: Carleton's histological technique, 5th ed. Oxford: Oxford University Press, 1980:49.

4 Edwards JL, Donalson JT. The time of fixation and the mitotic index. Am 7 Clin Pathol 1964;41:158-62.

5 Græm N, Helweg-Larsen K. Mitotic activity and delay in fixation of tumour tissue. Acta Pathol Microbiol ScandSection A Pathology 1979;87:375-8.

6 Cross SS, Start RD, Smith JHF. Does delay in fixation affect the number of mitotic figures in processed tissue? $f \mathrm{Cli}$ Pathol 1990;43:597-9.

7 Donhuijsen K, Schmidt U, Hirche H, Van Beuningen D Budach V. Changes in mitotic rate and cell cycle fraction caused by delayed fixation. Hum Pathol 1990;21:709-14.

8 Start RD, Flynn MS, Cross SS, Rogers K, Smith JHF. Is the grading of breast carcinomas affected by a delay in fixation?

9 McDowell EM, Trump BF. Histologic fixatives suitable for diagnostic light and electron microscopy. Arch Pathol Lab Med 1976;100:405-14

10 Elias JM, Gown AM, Nakamura RM, Wilbur DC, Herman GE, Jaffe ES, et al. Special report: quality control in immunohistochemistry. Report of a workshop sponsored by the Biological Stain Commission. Am f Clin Pathol 1989;92. 836-43.

11 Larsson L-I. Tissue preparation methods for light microscopic immunohistochemistry. Appl Immunohistochem 1993;1:2-16

12 Von Wasieleski R, Werner M, Nolte M, Wilkens L, Georgi A. Effects of antigen retrieval by microwave heating in formalin-fixed tissue sections on a broad panel of antibodies. Histochemistry 1994;102:165-72.

13 Feldman AT. The new goal: blurry nuclei ard hazy cytoplasm? $\mathcal{F}$ Histotechnol 1995;18:289-90.
14 Slater DN. Enclosed tissue system problem. IMLS gazette, vol 32. London: Headley Bros, 1988:83.

5 Anderson G. Enclosed tissue system problem. IMLS gazette, vol 32. London: Headley Bros, 1988:141-2.

16 Slater DN, Cobb N. Enclosed tissue processors. IMLS gazette, vol 32. London: Headley Bros, 1988:543-4.

17 Horikawa M, Chisaka N, Yokoyama S, Onoé T. Effect of stirring during fixation upon immunofluorescence results with distribution of albumin-producing cells in liver. $7 \mathrm{His}$ tochem Cytochem 1976;24:926-32.

18 Matthews JB. Influence of clearing agent on immunohistochemical staining of paraffin-embedded tissue. 7 Clin Pathol 1981;34:103-5.

19 Trevisan A, Gudat F, Busachi C, Stocklin E, Bianchi L. An improved method for $\mathrm{HBcAg}$ demonstration in paraffinembedded liver tissue. Liver 1982;2:331-9.

20 Collings LA, Poulter LW, Janossy G. The demonstration of cell surface antigens on T cells, B cells and accessory cells in paraffin-embedded human tissues. F Immunol Method 1984;75:227-39.

21 Cerio R, Macdonald DM. Effect of routine paraffin wax processing on cell membrane immunoreactivity in cutaneous tissue 7 Clin Lab Immunol 1986;20:97-100.

22 Tahan SR, Wei Y, Ling P, Bistrian BR. Influence of formalin fixation time and tissue processing method on immunoreactivity of monoclonal antibody PC 10 for proliferating cel nuclear antigen. Mod Pathol 1995;8:177-82.

23 Beebe K. Alcohol/xylene: the unlikely fixative/dehydrant clearant. Proceedings of the National Society for Histotechnology Annual Symposium. Buffalo, New York, October 7-13, 1995 .

24 Brain EB. Infiltrating histological specimens with paraffin wax under vacuum. Basic factors and a new approach. $B$ Dent F 1970;128:71-8.

25 Mepham BL, Britten KJM. Immunostaining methods for frozen and paraffin sections. In: Jones DB, Wright DH, eds. Lymphoproliferative diseases, vol 12. London: Kluwer, 1990 187-211.

26 Watkins J, Kellock D, Gillet C, Egan M, Pontin JE, Millis $\mathrm{RR}$, et al. Enhancement of immunostaining [letter]. Histopathology 1990;17:185.

27 Mallidis C, Volpe V, Ostor A, Lopata A, Baker HWG. Fixation and staining of testicular tissue. $\mathcal{F}$ Histotechnol 1994;17:111-14.

28 Fisher CJ, Gillett CE, Vojtesek B, Barnes DM, Millis RR. Problems with p53 immunohistochemical staining: the Problems with p53 immunohistochemical staining: the effects of fixation and variation in
evaluation. Brf Cancer 1994;69:26-31.

29 Wada T, Shimabukukuro T, Matsuyama H, Naito K, Skog $\mathrm{S}$, Tribukait B. Optimal conditions of fixation for immunohistochemical staining of proliferating cell nuclear antigen in tumour cells and its cell cycle related immunohistochemical expression. Cell Prolif 1994;27:541-51.

30 Raymond WA, Leong AS-Y. Oestrogen receptor staining of paraffin-embedded breast carcinomas following short fixation in formalin: a comparison with cytosolic and frozen section receptor analyses. F Pathol 1990;160:295-303.

31 Bromley CM, Palechek PL, Benda JA. Preservation of estrogen receptor in paraffin sections. I Histotechnol 1994;17:115-18.

32 Prioleau J, Schnitt SJ. p53 antigen loss in stored paraffin slides. N Engl f Med 1995;332:1521-2.

33 Shi S-R, Key ME, Kalra KL. Antigen retrieval in formalinfixed, paraffin-embedded tissues: an enhancement method for immunohistochemical staining based on microwave oven heating of tissue sections. F Histochem Cytochem 1991; 39:741-7.

34 Norton AJ, Jordan S, Yeomans P. Brief, high-temperature heat denaturation (pressure cooking): A simple and effective method of antigen retrieval for routinely processed tissues. F Pathol 1994;173:371-9.

35 Auld J. Antigen unmasking in routinely processed paraffin sections by pressure cooking. UK NEQAS-IC News. London: UK NEQAS-ICC, 1994(Spring):6-9.

36 Hopwood D. Fixation and fixatives. In: Bancroft JD, Stevens $\mathrm{A}$, eds. Theory and practice of histological techniques, 3rd ed, vol 2. Edinburgh: Churchill Livingstone, 1990:21-42.

37 Curran RC, Gregory J. Effects of fixation and processing on immunohistochemical demonstration of immunoglobulin in paraffin sections of tonsil and bone marrow. 7 Clin Patho 1980;33:1047-57.

38 Herman GE, Chlipala E, Bochenski G, Sabin L, Elfont E. Zinc formalin fixative for automated tissue processing. $\mathscr{f}$ Histotechnol 1988;11:85--9.

39 Carson FL, Martin JH, Lynn JA. Formalin fixation for electron microscopy: a re-evaluation. $\mathrm{Am} f \mathrm{Clin}$ Patho 1973;59:365-73

40 Lillie RD, Fullmer HM. Fixation. In: Histopathologic technic and practical histochemistry, 4th ed. London: McGraw-Hill, 1976:52 